\title{
Influence of anthropogenic features and traffic disturbance on burrowing owl diurnal roosting behavior
}

\author{
C. Scobie ${ }^{1, *}$, E. Bayne ${ }^{1}$, T. Wellicome ${ }^{1,2}$ \\ ${ }^{1}$ Department of Biological Sciences, CW 405, University of Alberta, Edmonton, Alberta T6G 2E9, Canada \\ ${ }^{2}$ Canadian Wildlife Service, Environment Canada, 925049 Street NW, Edmonton, Alberta T6B 1K5, Canada
}

\begin{abstract}
Birds that forage nocturnally should select daytime roosts that minimize predation risk to themselves, maximize their ability to warn mates or young about predators, and reduce their exposure to inclement weather. The objective of this study was to identify landscape features used by burrowing owls Athene cunicularia hypugaea during the day and to determine if traffic disturbance altered patterns of daytime space use. We tracked 17 adult male owls for 0.6 to $2.8 \mathrm{~d}$ each with GPS dataloggers and used resource utilization and resource selection functions to examine the response of each owl to nest burrows, perches, and roads. Selection for roads decreased as average vehicle speed increased. Roads with vehicle speeds $>80 \mathrm{~km} \mathrm{~h}^{-1}$ were avoided. Owls may avoid roads with high traffic speeds because auditory disturbance from passing vehicles interferes with their ability to communicate the presence of predators to their mates and young. Owls also spent more time near fences and posts, likely because these elevated perches are good vantage points for predator detection. Perches near burrowing owl nests should be maintained, and speed limits on roads near burrowing owl nests should be set to $<80 \mathrm{~km} \mathrm{~h}^{-1}$ to help ensure owls are able to effectively detect and react to predators.
\end{abstract}

KEY WORDS: Habitat selection $\cdot$ Roost $\cdot$ Traffic $\cdot$ Burrowing owl $\cdot$ Noise $\cdot$ Road

\section{INTRODUCTION}

Nocturnal birds must select daytime roosts that minimize predation risk and negative effects of adverse weather (Hayward \& Garton 1984, Belthoff \& Ritchison 1990, Churchill et al. 2000). Individuals balance these factors to maximize their own fitness (Kerth et al. 2001), but during the breeding season they may risk increased exposure to these elements to facilitate guarding mates and offspring (Sunde et al. 2003). The success of a reproductive event may rely on the ability of a parent to efficiently detect and react to threats (Gotmark et al. 1995, Magana et al. 2010), highlighting the significance of daytime roost characteristics for nocturnal species. The daytime activities of nocturnal animals is an understudied subject despite the higher predation risk that occurs during the day (Sunde et al. 2003) and a greater potential for disturbance from human activities.

The western burrowing owl Athene cunicularia hypugaea in Canada is an endangered species (Wellicome \& Haug 1995) that lives in the relatively flat, treeless grasslands. Lack of cover and an increasing human presence in these grasslands leaves this nocturnal species potentially susceptible to disturbance during the day. Almost all foraging activities occur at night (Poulin \& Todd 2006), and thus past research has focused on minimizing human impacts during the night (Sissons 2003, Grzywaczewski 2009, Williams et al. 2011). Little is known about owl behavior during the day, when most human activities occur and predation risk is assumed 
to be high, so understanding the diurnal space use patterns of owls may be crucial in mitigating disturbance effects.

Burrowing owls nest in underground burrows, where the female spends most of her time incubating eggs and brooding chicks (Plumpton \& Lutz 1993). The concealed nature of their nests minimizes predation risk (Martin \& Li 1992), but escape is almost impossible if owls are in the burrow when a predator enters. Mammalian predators are the most common nest predators (Wellicome 2000), but after brooding, the female and young spend more time above ground near the burrow entrance (Plumpton \& Lutz 1993), where they are susceptible to avian predators (Shyry 2005). Throughout the nesting period, the male remains above ground (Plumpton \& Lutz 1993), though during the day the male spends little time capturing prey (Poulin \& Todd 2006). Observations suggest that male burrowing owls spend most of the day on elevated perches, engaging in vigilance behavior (Plumpton \& Lutz 1993, Chipman et al. 2008). Prior to European settlement of the prairies, burrowing owls likely relied on burrow mounds, rocks, and hilltops as elevated perches, but may now rely on anthropogenic perches such as fence posts which are prolific in the landscape. From these perches, the male actively defends his nest and uses auditory signals to communicate risks to his mate and young (Martin 1973a,b). Anthropogenic noise may hinder the ability to give or receive such acoustic signals (Brumm 2004, Bee \& Swanson 2007, Parris \& Schneider 2009, Lampe et al. 2012), so owls may avoid roosting where noise levels are high. However, anthropogenic perches in the western prairies tend to be close to roads, so the value of roosts may vary as a function of whether they are adjacent to quiet versus noisy roads. Therefore, landscape features and anthropogenic activities near the nest that influence the ability of male owls to detect predators and communicate predation risk to the female or young need to be determined.

To evaluate this, we examined diurnal space use of adult male burrowing owls wearing GPS dataloggers to identify landscape features used by burrowing owls during the day. We then determined if disturbance from traffic altered the patterns of daytime space use by male burrowing owls. We predicted that males would select elevated perches to maximize detection of predators when close to the nest and avoid noisier areas to facilitate acoustic communication with the female and young.

\section{MATERIALS AND METHODS}

Between 2007 and 2009, 387 burrowing owl nesting attempts within the dry mixed-grass ecoregion of southern Alberta and Saskatchewan, Canada, were found and monitored, and the adult male was tracked with a GPS datalogger at 18 of these nests (Fig. 1). Nests were located in early May using call playback surveys, and were visited once per week throughout the breeding season. After the chicks hatched, each adult male owl was captured by means of either a 1-way walk-in (Winchell 1999) or a bownet trap baited with a dead mouse, a speaker playing a burrowing owl primary call, a decoy burrowing owl, or a combination thereof. A $7 \mathrm{~g}$ GPS datalogger (TechnoSmArt) was attached to each owl, using Teflon ribbon in a backpack-style configuration. The dataloggers we used were upgraded by the manufacturer each year, resulting in varying program schedules. Dataloggers were programmed to turn on and take 2 fixes every $15 \mathrm{~min}$ (2007), turn on for $5 \mathrm{~min}$ and take 1 location every second, then turn off for $55 \mathrm{~min}$ (2008), or to take 1 location every second continuously (2009). The following data were stored on internal memory within the GPS datalogger: latitude, longitude, speed, altitude, dilution of precision, Greenwich Mean Time, and date. To retrieve the data, owls were re-trapped after $3 \mathrm{~d}$ once the GPS micro-data-

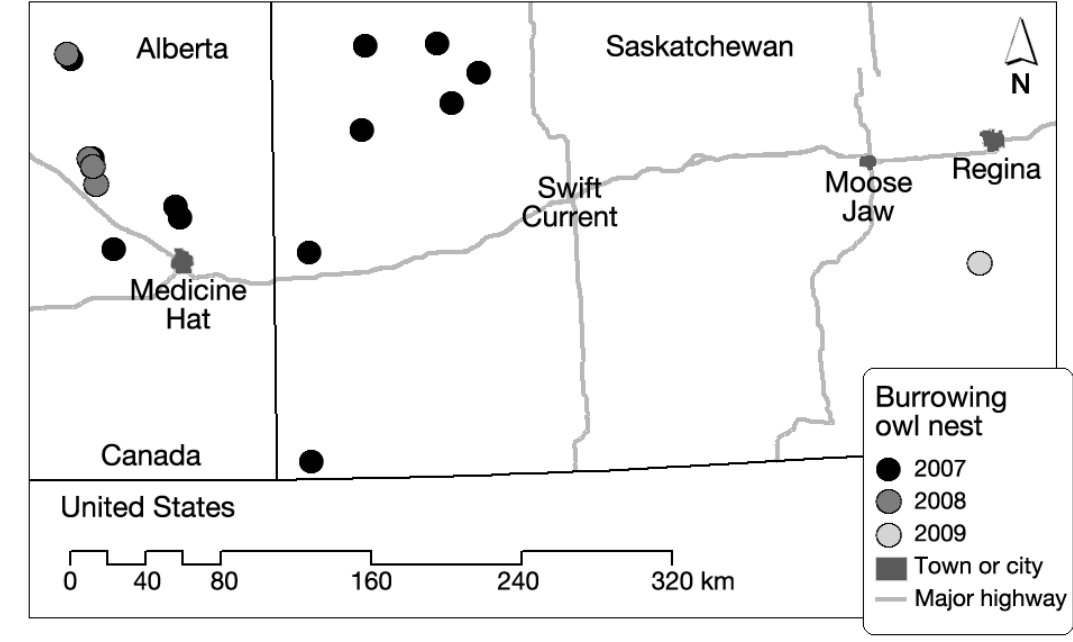

Fig. 1. Athene cunicularia hypugaea. Distribution of burrowing owl nests from which the adult male was tracked with a GPS datalogger during the day 


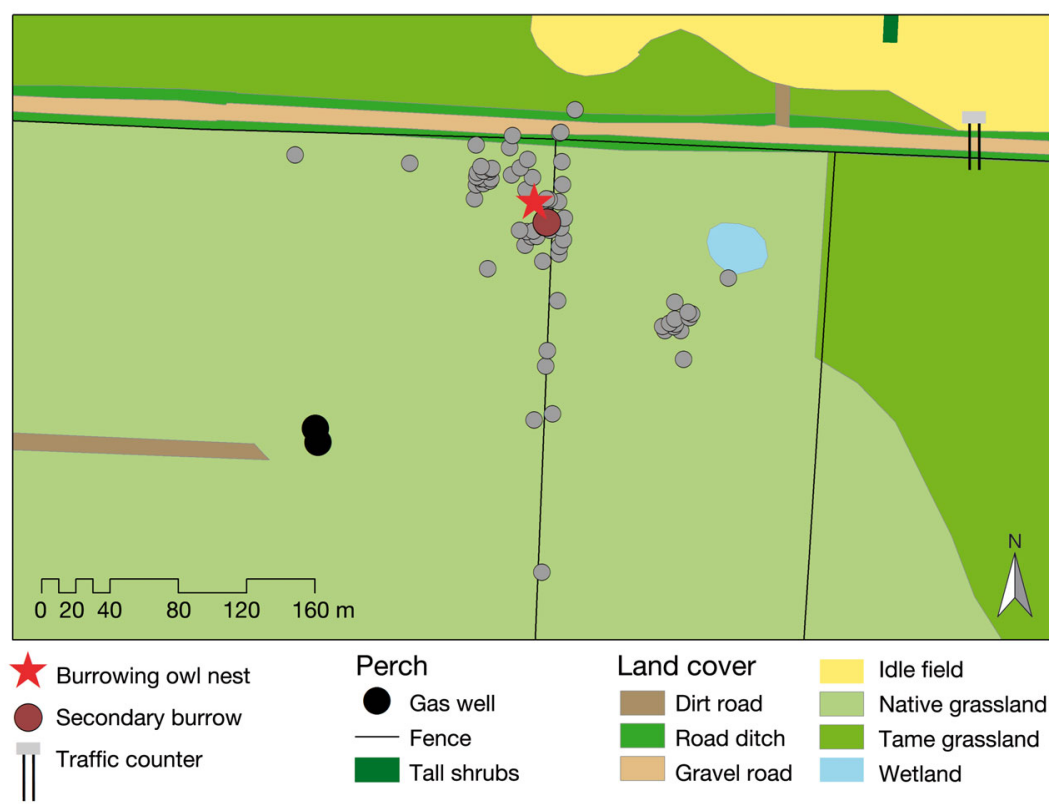

Fig. 2. Athene cunicularia hypugaea. Datalogger locations (O) and landscape around 1 burrowing owl nest

logger battery was depleted. Owl locations were filtered by dilution of precision $(\leq 1.5)$, speed $(\leq 64 \mathrm{~km}$ $\left.\mathrm{h}^{-1}\right)$, and altitude $(>20 \mathrm{~m}$ below and $<80 \mathrm{~m}$ above the elevation of the owl's nest). Dilution of precision is a measure of the accuracy of a GPS location calculated using the number and location of satellites relative to the GPS datalogger. A dilution of precision close to 1 is the most precise. One location every $15 \mathrm{~min}$ (2007 and 2009), or 1 location every hour (2008), was selected for these analyses. To avoid inclusion of locations from crepuscular foraging activities, we included in our analyses only those locations taken between $1 \mathrm{~h}$ after sunrise and $1 \mathrm{~h}$ before sunset (Poulin \& Todd 2006). The accuracy of the GPS dataloggers was tested by measuring the distance between locations from a stationary GPS datalogger placed on a fence post in the field for $3 \mathrm{~d}$ and the stationary datalogger's location as determined with a hand-held GPS unit. All data were collected by trained field staff in possession of valid animal care approval, federal and provincial research permits, and bird-banding licenses.

GPS datalogger locations were used to calculate fixed kernel density for each owl with the least squared cross validation method for calculating bandwidth in the adehabitat package (Calenge 2006) in R. The fixed kernel was determined for a 5 by $5 \mathrm{~m}$ pixel, a resolution that matches the accuracy of the GPS datalogger. Kernel density bandwidth was calculated using least squared cross validation because it is the best method for a central place forager with
$>20$ locations per animal when mapping areas of highest concentration of use (Gitzen et al. 2006). Kernel density for each owl was transformed to utilization distributions by dividing the kernel value for each pixel by the sum of the kernel values for all pixels combined.

Each year, land cover and perches surrounding the nest of each tracked owl were recorded on aerial photographs. These aerial photographs were digitized in a GIS environment onto SPOT5 imagery (Fig. 2). Locations of the nest burrow and secondary burrows (any burrow where $\geq 5$ pellets were observed over the nesting period) were recorded with handheld GPS units. Land cover types (native grassland, tame grassland, crop, idle field, wetland [sparse vegetation and seasonally dry, including during our study], road ditch, dirt road, gravel road, and paved road) were all included in statistical models, with native grassland being the reference category.

Prior to analyses, all data were evaluated for outliers, homogeneity, normality, collinearity among covariates, potential interactions, and independence of the response variable (Zuur et al. 2010). When collinearity was detected, the variable with the highest variation inflation factor was removed, and the variation inflation factor was then recalculated for each variable. This was repeated until all variation inflation factors were $<3$ (Quinn \& Keough 2002). All models were validated by looking for influential observations, residual homogeneity, independence of covariates, normality of residuals, and spatial independence (Zuur et al. 2007).

Land cover and distance to nearest perches, burrows, and roads were extracted, for each pixel of the utilization distribution (Fig. 3), and examined using a resource utilization function (RUF). Initial data exploration revealed outliers and lack of normality for the utilization distribution for each owl, so they were logtransformed prior to analysis. There was also strong evidence for spatial dependence among the utilization distribution values for each owl, so spatial regression using spatial simultaneous autoregressive error model estimation was used (Bivand 2013). Land cover and distance to nearest perch, nest burrow, secondary burrow, and each class of road type (dirt, gravel, paved) were determined for each utilization 


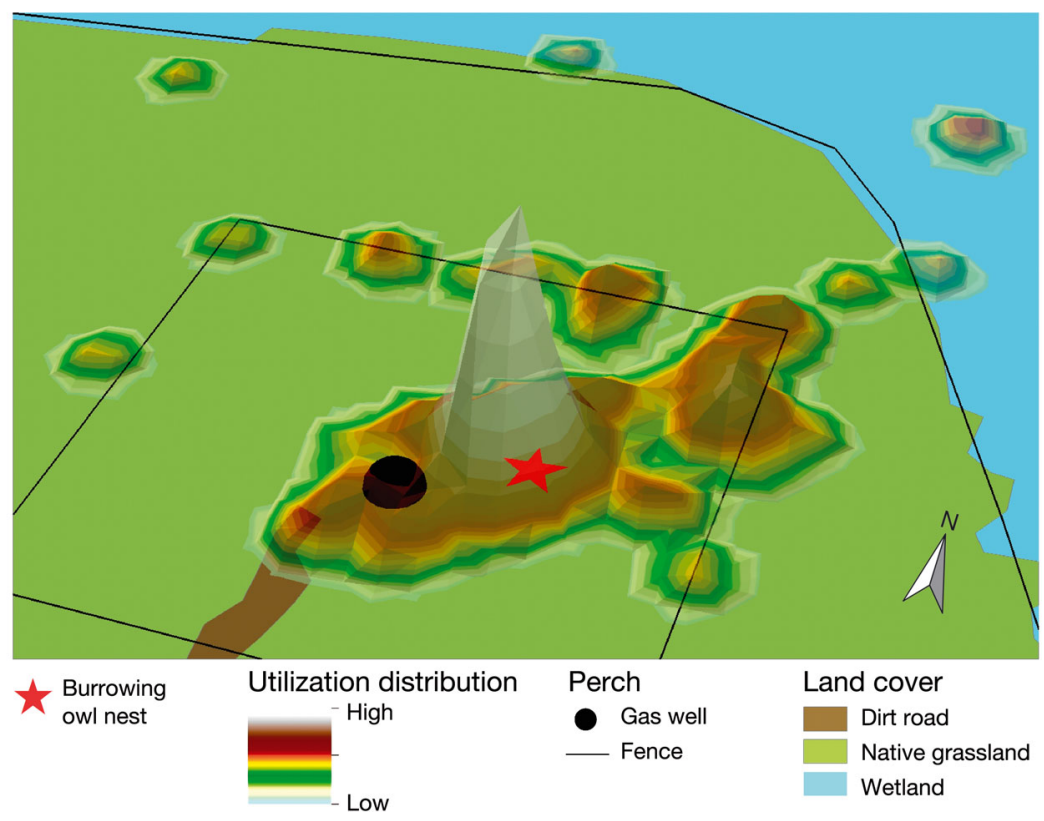

Fig. 3. Athene cunicularia hypugaea. Utilization distribution of 1 owl showing land cover, perches, and nest burrow

a radius around each nest equal to the furthest distance the adult male owl travelled from the nest during the tracking period (Glenn et al. 2004). Land cover and distance to nearest perch, nest burrow, secondary burrow, and each class of road type (dirt, gravel, paved) were determined for each owl datalogger location and each random location. Distance to the nearest perches and roads was limited to features that were within a radius equal to the furthest distance the owl travelled plus 100 and $500 \mathrm{~m}$, respectively. This distance was selected for perches because owls may choose to be in areas with readily accessible perches nearby (within $\sim 100 \mathrm{~m}$ ), and factors that may result in avoidance, such as predator use of these perches, are likely of little concern when owls are further than $100 \mathrm{~m}$ from perches. We included

distribution pixel. Collinearity between these covariates was examined for each owl using the aforementioned method, and the model for each owl contained all variables that were used by that owl (overlapped the $100 \%$ kernel) and had variation inflation factors $<3$ (Quinn \& Keough 2002). The coefficients and standard errors from the model for each owl were then used to calculate the inverse variance weighted mean, standard error, $z$-value, and p-value for each covariate for the entire sample of owls. The negative coefficients are presented for distance variables, so that the response of the owl (attracted versus avoided) matches the signs (positive versus negative) of the coefficients for the other variables. Use of roads as a land cover variable was further examined by comparing the relative concentration of use. This was done by calculating the average utilization distribution value for each land cover type for each owl (excluding all utilization distribution values for each owl for the land cover in which the nest was embedded), then calculating the inverse variance weighted mean and standard error. Removal of the utilization distribution values for the land cover in which the nest was embedded helps adjust for the inflated values that result near the nest from the clustering of owl locations at the nest burrow.

A resource selection function (RSF) was also used to examine owl space use in relation to land cover, burrows, perches, and roads. Five random locations were generated for each datalogger location, within roads up to this distance because owls are able to hear vehicles driving on roads $500 \mathrm{~m}$ away, but beyond this distance the visual disturbance is likely not perceived as a threat because there would be plenty of time for an owl to react if a threat were present. The model for each owl contained all covariates with variation inflation factors $<3$. A generalized linear model with a binomial error and logit link was used to analyze the data for each owl. Random locations were given one-fifth the weight of the datalogger locations of used points when computing statistical significance (see Aldridge \& Boyce 2007). Again, a 2-step approach was used, whereby the coefficients and standard errors from the model for each owl were used to calculate the inverse variance weighted mean, standard error, $z$-value, and $p$-value for each covariate. As was done for the RUF, the negative coefficients are presented for distance variables. Selection ratios for each land cover type were also calculated (Manly et al. 2002) for each owl, while excluding all of the owl and random locations that occurred in the land cover type in which the nest was embedded. This was done to reduce a bias toward the land cover type in which the nest was embedded, which can result from clustering of locations near the nest. The selection ratio for each owl was then used to calculate the inverse variance weighted mean and standard error for each land cover type.

We also looked at percentages of locations on roads and perches. The number of GPS datalogger loca- 
tions on each type of road and the number of locations within $5 \mathrm{~m}$ (equal to GPS datalogger error) of a perch were each divided by the total number of locations for that owl. The resulting values were then averaged across all owls to estimate percentage of time adult male owls spend on these features.

We subsampled 1 location $\mathrm{h}^{-1}$ from the datalogger locations from 2007 and 2009 and re-ran the RSF models for these 14 owls to confirm that different sampling frequencies between years did not influence our results. Although the standard errors changed for some estimates, the direction of the response of the owls (attracted versus avoided) did not change for variables with samples from $>1$ owl (Table S1 in the Supplement at www.int-res.com/ articles/suppl/n024p073_supp.pdf). Differences in sampling frequency would not significantly affect the utilization distribution for each owl because the number of locations would have a negligible effect on the kernel density estimation for each owl. One owl did not have the reference land cover available (native grass), so the land cover coefficients and standard errors from that 1 owl were excluded from the inverse variance weighted mean for both the RUF and RSF. All statistical analyses were performed in R (R Development Core Team 2012).

\section{Traffic}

Traffic and road characteristic data were collected from roads that ran near burrowing owl nests in our study. Pneumatic tube traffic counters (MetroCount; MC5600 Series Roadside Unit) were deployed on 11 roads, 1 of which ran near 2 nests. Traffic counters recorded each vehicle that passed, vehicle speed, and vehicle class. Traffic counter data from 2 roads were collected simultaneous to the deployment of dataloggers, and data from the remaining roads were collected the following summer. All roads were within a distance from the nest equal to the maximum distance that owl travelled from the nest plus $500 \mathrm{~m}$. Two of those roads were paved, 1 was dirt, and the rest were gravel. Each traffic counter collected data for at least 21 consecutive days to enable us to calculate average traffic volume, speed, and percent of heavy vehicles with minimal bias from single traffic events (e.g. holidays, ranching events, etc.). Data collected from the traffic counters were used to calculate average hourly daytime traffic volume, average speed, and percent of heavy vehicles during the same period of the day ( $1 \mathrm{~h}$ after sunrise to $1 \mathrm{~h}$ before sunset) and period of the week (weekday vs. week- end) that the owls were tracked. Vehicles were identified as belonging to 1 of 14 classes using the method developed by the United States Federal Highway Administration (Federal Highway Administration 1999). Vehicle classes F8 to F13 were aggregated into a heavy vehicle category that was used to calculate the average percent of heavy vehicles that travelled on each road. Road width, ditch width, distance from road to nest, presence of fences, and road surface type were documented for each of these roads as well. Traffic and road characteristics for each monitored road are presented in Table S2 in the Supplement at www.int-res.com/articles/suppl/n024p073 _supp.pdf.

We examined the response of the owls nesting near these roads to the traffic and road characteristics using weighted linear regression. The negative coefficient from the RSF was used as the response of each owl, and the weighting was the inverse of the variance of that coefficient. Data exploration identified that traffic volume and road width had the greatest variation inflation factors, so both were run in separate models with no other covariates. One observation had a very large influence (weighted Cooks distance $=38.8$, so it was removed from the final models. Models containing all possible combinations of uncorrelated variables were compared with corrected Akaike's information criterion (Burnham \& Anderson 2002) to determine which variables most influenced the owls' responses to roads.

\section{Sound}

To explore the relationship between vehicle speed, road surface type, and sound, we measured sound from a single vehicle driving past a stationary sound meter. These sound measurements were taken on roads at least $50 \mathrm{~km}$ away from any owl nest sites. A handheld Brüel \& Kjær Type 2250 sound level meter was used to measure the sound made by a passing 2 axle passenger vehicle driving on a dirt road at 20 , 40 , and $60 \mathrm{~km} \mathrm{~h}^{-1}$, a gravel road at $60,80,100$, and $110 \mathrm{~km} \mathrm{~h}^{-1}$, and a paved road at 80,100 , and $120 \mathrm{~km} \mathrm{~h}^{-1}$. The sound meter microphone was held 6 to $7 \mathrm{~m}$ horizontally from the passing vehicle and $1 \mathrm{~m}$ off the ground. The maximum sound power level $\left(L S_{\max }\right)$ was calculated for each one-third octave band between 500 and $10000 \mathrm{~Hz}$ for each road surface type and speed. The formulae from International Standard 3746:2010 (ISO 2010) were adapted for these calculations. A burrowing owl audiogram was not available, so the lower hearing threshold was 
determined from the behavioral audiogram of an eastern screech owl Megascops asio (Brittan-Powell et al. 2005) and converted to a weighting. This weighting was applied to the vehicle sound power levels, giving owl-weighted sound power levels (dBO), which more accurately depict the burrowing owls' perception of the sounds (Pater et al. 2009). Linear regression was used to examine the relationship between vehicle speed and owl-weighted sound power levels.

\section{RESULTS}

We tracked 17 burrowing owls for an average of $1.7 \mathrm{~d}(\mathrm{SD}=0.55)$ each and gathered a total of 1428 independent GPS micro-datalogger locations (mean $=79$, range $=24$ to 150 ). The GPS dataloggers were successful in obtaining fixes $91 \%$ of the time (range = 62 to $100 \%$ ). Locations from the stationary test datalogger with a dilution of precision $\leq 1.5$ were an average of $4.26 \mathrm{~m}(\mathrm{SD}=2.94)$ from the test location. One owl was tracked in 2007 and again in 2008, for a total of 18 tracking events (13 in 2007, 4 in 2008, and 1 in 2009). All owls were tracked after the eggs hatched, but before the juveniles were able to fly (range: 7 to $22 \mathrm{~d}$ after hatch). The average $95 \%$ minimum convex polygon (MCP) was 2.59 ha, the average $95 \%$ kernel was $0.49 \mathrm{ha}$, and the average maximum distance travelled from the nest during the day was $250 \mathrm{~m}$ (Table 1). Details about the number of locations, tracking duration, and home range characteristics for each individual owl can be found in Table S3 in the Supplement at www.int-res.com/articles/suppl/n024 p073_supp.pdf

The least squared cross validation would not converge for 1 owl when calculating the bandwidth for the fixed kernel, so it was excluded from the RUF analysis. Owls were significantly attracted to nest burrows, with all 18 owls showing a positive response in the RSF and all but 2 owls showing a positive response in the RUF. Our sample of owls was significantly attracted to fences and posts, but selection of posts differed somewhat between individuals (Table 2). On average, owls spent $17.4 \%$ (range $=0$ to $55.0 \%$ ) of their time on fences (Fig. 4). Three owls had tall perches ( 2 with tall shrubs and 1 with a power line) near their nests, but none used these tall features as perches (Fig. 4).
Collinearity with other covariates resulted in the removal of these features from the RSFs for 2 owls, but the model for the remaining owl showed avoidance of tall shrubs (Table 2).

The RSF shows that the number of owls attracted to dirt roads was less than the number that avoided them, but the inverse weighted mean indicates significant attraction, a result driven by a few owls that were greatly attracted to dirt roads (Table 2 ). The results of both RSF and RUF show that owls are almost equally divided between attraction and avoidance of gravel roads (Table 2). Our analysis of road types as land cover show significant attraction to gravel road surfaces compared to available (selection ratios; Fig. 5) and significantly higher use of gravel road surfaces than other land cover types (concentration of use; Fig. 5). On average, owls spent $13.5 \%$ of their time on roads of any type, but the bulk (9.7\%) was spent on gravel roads (Fig. 4). Only a few owls had paved roads near their nests, and their responses to this road type varied between individuals and the 2 analyses (Table 2).

\section{Traffic}

We further explored the responses of owls to roads as a function of traffic and road characteristics. These roads were on average $146.9 \mathrm{~m}(0$ to $679 \mathrm{~m}$ ) from the nest, the average ditch width was $11.9 \mathrm{~m}(0$ to $30 \mathrm{~m}), 5$ roads had at least 1 fence present, average vehicle speed was $79.1 \mathrm{~km} \mathrm{~h}^{-1}$ (50.9 to $103.9 \mathrm{~km} \mathrm{~h}^{-1}$ ), average traffic volume was 2.7 vehicles $\mathrm{h}^{-1}\left(0.12\right.$ to 16.25 vehicles $\left.\mathrm{h}^{-1}\right)$, and average proportion of heavy vehicles was 0.10 (0 to 0.25$)$. The top model (Table 3 ) contained average hourly vehicle speed $(\beta=-1.21, \mathrm{SE}=0.28, \mathrm{p} \leq 0.01)$. This significant negative relationship between owl

Table 1. Athene cunicularia hypugaea. Spatial characteristics of adult male burrowing owl diurnal home ranges. The 'maximum distance from nest' method of home range size estimation uses the distance the owl travelled from the nest, and the area is estimated assuming a circular daytime home range; all other methods use area and calculate the radius of a circle around the nest with an equivalent area. MCP: minimum convex polygon

\begin{tabular}{|lcccrrr|}
\hline Method & $\begin{array}{c}\text { Radius } \\
\text { (mean; } \mathrm{m})\end{array}$ & $\begin{array}{c}\text { Area } \\
\text { (mean; ha) }\end{array}$ & Min. & Max. & SE & $\begin{array}{c}\text { No. of } \\
\text { owls }\end{array}$ \\
\hline 100\% kernel & 67.73 & 1.44 & 0.14 & 8.41 & 0.5 & 17 \\
$95 \%$ kernel & 39.35 & 0.49 & 0.03 & 2.98 & 0.2 & 17 \\
100\% MCP & 108.43 & 3.69 & 0.33 & 31.64 & 1.7 & 18 \\
$95 \%$ MCP & 90.74 & 2.59 & 0.13 & 30.11 & 1.6 & 18 \\
Max. dist. from nest & 250.29 & 19.68 & 60.53 & 838.64 & 43.3 & 18 \\
\hline
\end{tabular}


Table 2. Athene cunicularia hypugaea. Resource selection function (RSF) and resource utilization function (RUF) for 18 burrowing owl tracking events during the summers of 2007, 2008, and 2009. Results for land cover selection and use were omitted for 1 owl that did not have native grass near its nest. There are different numbers of owls for some covariates between the RSF and RUF because different covariates were removed due to collinearity. 'Owl response' signifies attraction (+) or avoidance (-)

\begin{tabular}{|c|c|c|c|c|c|c|c|c|c|c|c|c|}
\hline \multirow{3}{*}{ Covariate } & \multirow{3}{*}{$\beta$} & \multirow{3}{*}{$\mathrm{SE}$} & \multirow{3}{*}{$\begin{array}{l}-\mathrm{RSF} \\
\mathrm{p}\end{array}$} & \multirow{2}{*}{\multicolumn{2}{|c|}{$\begin{array}{c}\text { Owl } \\
\text { response }\end{array}$}} & \multirow{3}{*}{$\mathrm{n}$} & \multirow{3}{*}{$\beta$} & \multirow{3}{*}{ SE } & \multirow{3}{*}{$-{ }_{\mathrm{p}}^{\mathrm{RUF}}$} & \multirow{2}{*}{\multicolumn{2}{|c|}{$\begin{array}{c}\text { Owl } \\
\text { response }\end{array}$}} & \multirow{3}{*}{$\mathrm{n}$} \\
\hline & & & & & & & & & & & & \\
\hline & & & & + & - & & & & & + & - & \\
\hline Intercept & 3.18 & 0.27 & $<0.01$ & 3 & 15 & 18 & -1.90 & 0.05 & $<0.01$ & 1 & 16 & 17 \\
\hline \multicolumn{13}{|l|}{ Burrow $^{a}$} \\
\hline Nest & 11.12 & 1.19 & $<0.01$ & 18 & 0 & 18 & 0.32 & 0.05 & $<0.01$ & 14 & 2 & 16 \\
\hline Secondary burrow & 9.18 & 6.85 & 0.09 & 1 & 1 & 2 & 3.67 & 1.22 & $<0.01$ & 4 & 0 & 4 \\
\hline \multicolumn{13}{|l|}{ Land cover } \\
\hline Crop & -0.39 & 0.55 & 0.24 & 0 & 4 & 4 & 0.03 & 0.09 & 0.39 & 2 & 0 & 2 \\
\hline Dirt road & 0.33 & 0.48 & 0.25 & 5 & 8 & 13 & -0.08 & 0.05 & 0.04 & 2 & 6 & 8 \\
\hline Gravel road & 0.20 & 0.51 & 0.35 & 3 & 4 & 7 & -0.01 & 0.05 & 0.54 & 1 & 3 & 4 \\
\hline Idle field & 6.68 & 1.36 & $<0.01$ & 1 & 3 & 4 & -0.08 & 0.18 & 0.33 & 1 & 1 & 2 \\
\hline Paved road & -2.40 & 2.40 & 0.16 & 0 & 1 & 1 & -0.19 & 0.06 & $<0.01$ & 0 & 1 & 1 \\
\hline Road ditch & -0.65 & 0.82 & 0.21 & 0 & 4 & 4 & -0.14 & 0.03 & $<0.01$ & 0 & 3 & 3 \\
\hline Tame grass & -0.70 & 0.50 & 0.08 & 1 & 4 & 5 & -0.07 & 0.04 & 0.02 & 0 & 4 & 4 \\
\hline Wetland & 1.16 & 0.55 & 0.02 & 4 & 8 & 12 & 0.05 & 0.05 & 0.15 & 4 & 4 & 8 \\
\hline \multicolumn{13}{|l|}{ Perch $^{a}$} \\
\hline Dugout spoil pile & 1.71 & 5.44 & 0.38 & 1 & 0 & 1 & - & - & - & - & - & - \\
\hline Fence & 12.37 & 3.53 & $<0.01$ & 7 & 3 & 10 & 3.69 & 1.25 & $<0.01$ & 8 & 3 & 11 \\
\hline Gas well head & 10.71 & 2.19 & $<0.01$ & 1 & 3 & 4 & 2.08 & 1.81 & 0.13 & 2 & 1 & 3 \\
\hline Post & 23.17 & 10.81 & 0.02 & 1 & 1 & 2 & 2.69 & 1.54 & 0.04 & 2 & 1 & 3 \\
\hline Tall shrubs & -16.63 & 11.80 & 0.08 & 0 & 1 & 1 & - & - & - & - & - & - \\
\hline \multicolumn{13}{|l|}{ Road $^{a}$} \\
\hline Dirt & 5.06 & 2.84 & 0.04 & 3 & 5 & 8 & 0.53 & 0.15 & $<0.01$ & 1 & 0 & 1 \\
\hline Gravel & -0.17 & 3.17 & 0.48 & 4 & 5 & 9 & -0.38 & 1.01 & 0.35 & 2 & 2 & 4 \\
\hline Paved & 6.52 & 2.17 & $<0.01$ & 1 & 1 & 2 & 0.26 & 0.22 & 0.12 & 1 & 0 & 1 \\
\hline
\end{tabular}

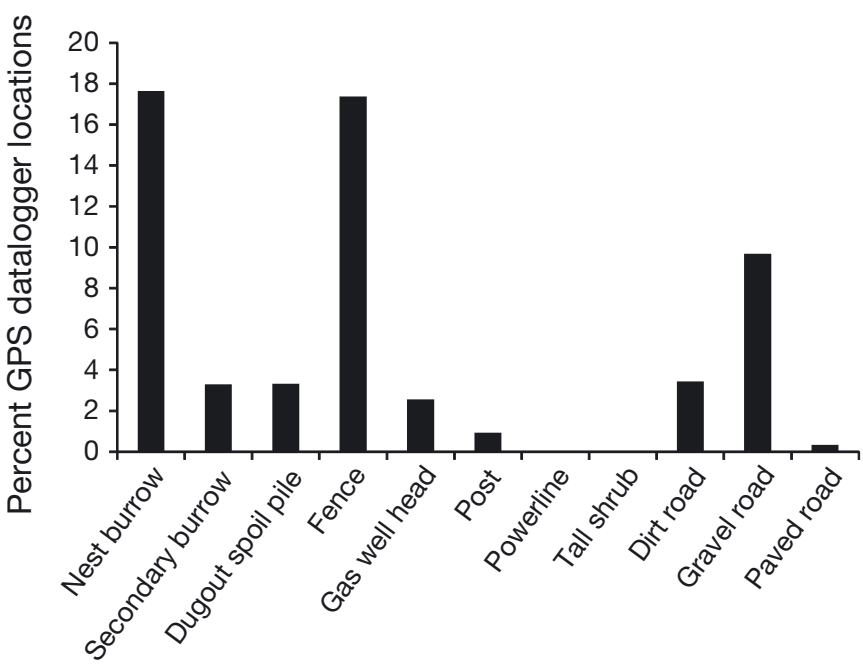

Fig. 4. Athene cunicularia hypugaea. Average percent of burrowing owl locations within $5 \mathrm{~m}$ of burrows and perches and on roads

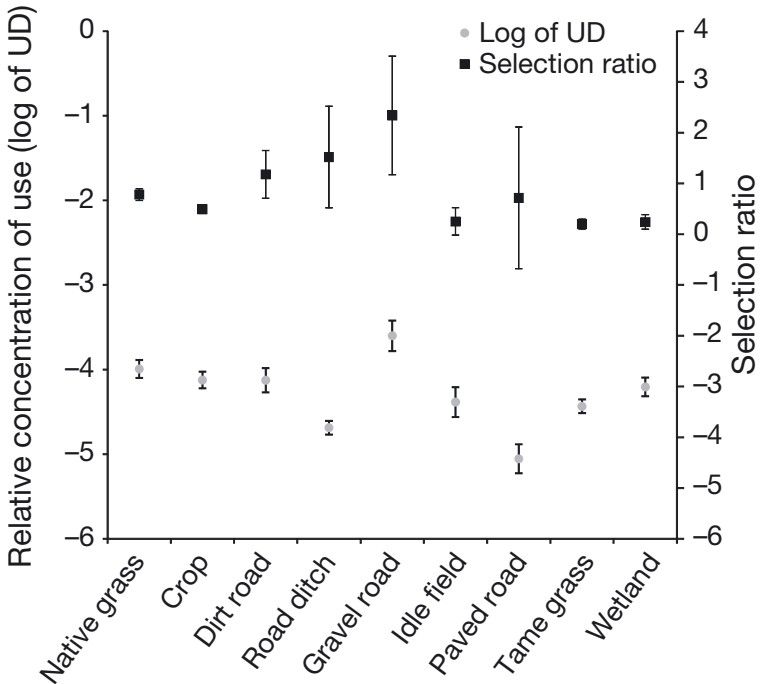

Fig. 5. Athene cunicularia hypugaea. Weighted average relative concentration of use and weighted average selection ratios of different land cover types by adult male burrowing owls during the day. For each owl, all utilization distribution values and owl and random locations for the land cover in which the nest was embedded were excluded. Utilization distribution (UD) is log-transformed. Error bars are $95 \%$ confidence intervals 
Table 3. Athene cunicularia hypugaea. The top 12 models explaining owl selection of roads with varying characteristics. Models were developed using weighted least squares regression. $k$ : no. of parameters; AICc: corrected Akaike's information criterion; $w$ : Akaike weight

\begin{tabular}{|lcccc|}
\hline Model & $k$ & AICc & $\Delta$ AICc & $W$ \\
\hline Speed & 2 & 100.3 & 0.0 & 0.622 \\
Speed + ditch width & 3 & 102.1 & 1.8 & 0.256 \\
Speed + fence & 3 & 105.0 & 4.7 & 0.060 \\
Distance to nest & 2 & 107.5 & 7.2 & 0.017 \\
Speed + ditch width + fence & 4 & 108.3 & 8.0 & 0.011 \\
Speed + ditch width + distance to nest & 4 & 108.4 & 8.1 & 0.011 \\
Null & 1 & 108.6 & 8.3 & 0.010 \\
Speed + ditch width + percent & 4 & 109.2 & 8.9 & 0.007 \\
$\quad$ heavy vehicles & & & & \\
Fence & 2 & 110.9 & 10.6 & 0.003 \\
Ditch width & 2 & 112.5 & 12.2 & 0.001 \\
Percent heavy vehicles & 2 & 112.5 & 12.2 & 0.001 \\
Speed + ditch width + fence + & 5 & 116.6 & 16.3 & 0.000 \\
$\quad$ percent heavy vehicles & & & & \\
\hline
\end{tabular}

response to roads and average daytime vehicle speed was consistent across all models containing this variable. Owls were attracted to roads with lower average daytime traffic speeds, but began avoiding roads (negative RSF coefficient switched from positive to negative) when average daytime traffic speeds were $>80 \mathrm{~km} \mathrm{~h}^{-1}$ (Fig. 6).

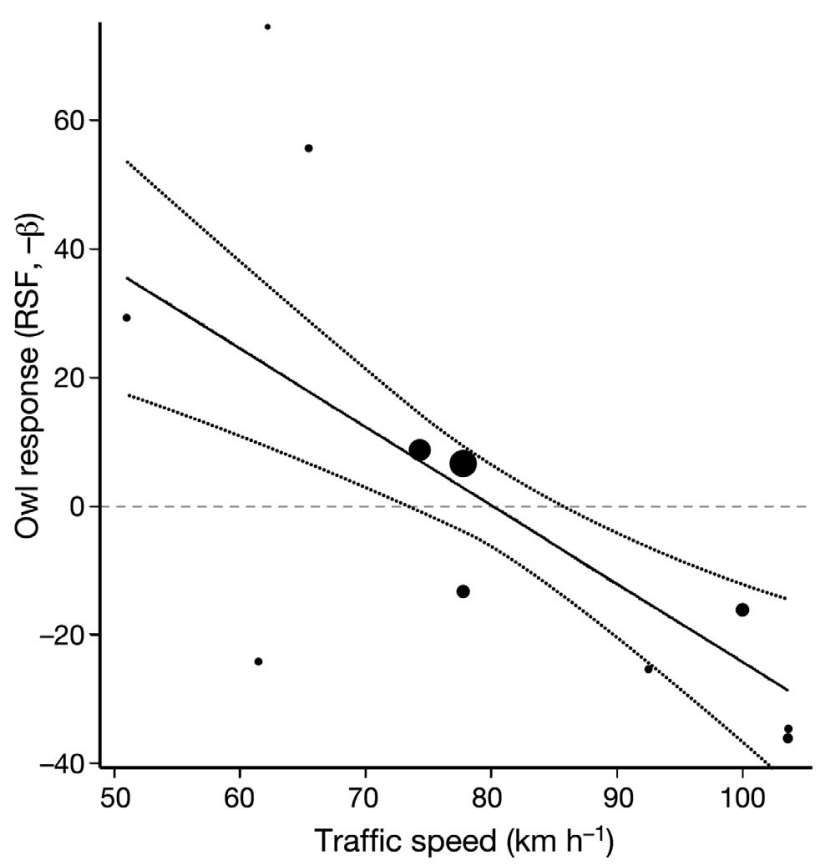

Fig. 6. Athene cunicularia hypugaea. Predicted response of owls to roads as a function of vehicle speed, derived from weighted regression. Sizes of dots on the figure are proportional to their weightings. Dotted lines represent $95 \%$ confidence intervals. RSF: resource selection function

\section{Sound}

At least 9 trials per surface type and speed (except $40 \mathrm{~km} \mathrm{~h}^{-1}$ on the dirt road and $110 \mathrm{~km} \mathrm{~h}^{-1}$ on the gravel road, which had 5 and 2 trials, respectively) were used to calculate sound power levels. Owl-weighted sound power levels increased significantly as vehicle speed increased $(\beta=0.259$, $t=8.71, \mathrm{p} \leq 0.01$ ) (Fig. 7). The overall model fit was $\mathrm{R}^{2}=0.90$. The owlweighted sound pressure level when traffic is moving at $80 \mathrm{~km} \mathrm{~h}^{-1}$ is $86.2 \mathrm{~dB}(\mathrm{SE}=0.90)$. The A-weighted sound pressure level (weighted to human hearing) at that speed is 96.1 $\mathrm{dB}(\mathrm{SE}=1.02)$.

\section{DISCUSSION}

Burrowing owls avoided roads with higher traffic speeds, which are highly correlated with sound levels, giving support to our hypothesis that owls avoid noisy areas during the day. Other studies have found that passerine density in areas near roads was not related to the visual disturbance caused by high volumes of traffic (Reijnen et al. 1995), but that vehicle speed better predicted reduced abundance (Reijnen et al. 1995, 1996). Sound from traffic increases with vehicle speed (Stephen 2005), and greater sound levels could hinder the ability of owls

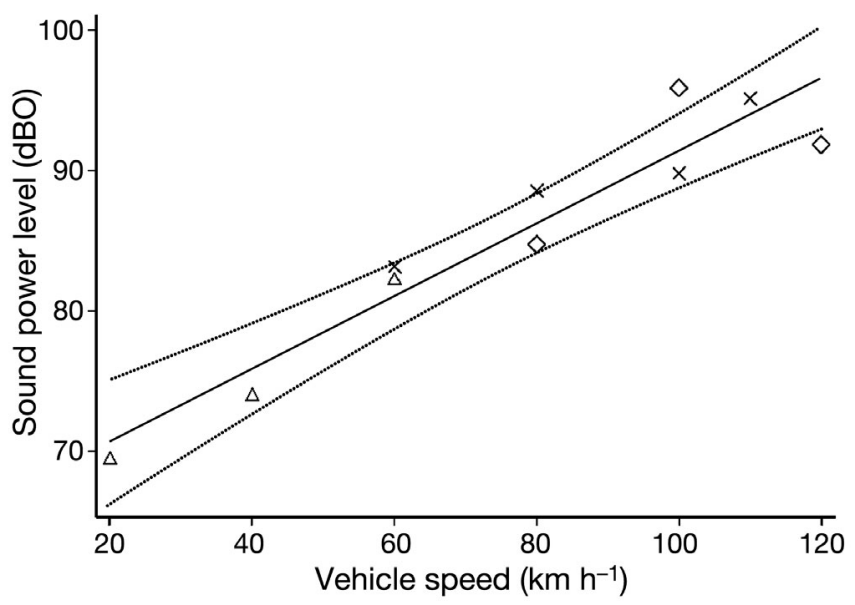

Fig. 7. Athene cunicularia hypugaea. Average owl-weighted broadband sound power level $(\mathrm{dBO})$ of a half tonne pick-up truck driving on dirt $(\Delta)$, gravel $(x)$, and paved $(\diamond)$ roads. Dotted lines represent $95 \%$ confidence intervals 
to communicate with their mate and young (Rheindt 2003). Traffic volume and proportion of heavy vehicles are also important variables that affect sound emissions from traffic (Besnard et al. 2009), but the effect they had on sound levels from the roads we monitored was negligible. Irrespective of why owls avoid roads with greater vehicle speeds, the data we present here indicate it would be beneficial to owl habitat if vehicle speed were $<80 \mathrm{~km} \mathrm{~h}^{-1}$ near burrowing owl nests.

Owls selected and showed increased use of both fence lines and posts, indicating predator vigilance is a priority for male owls during the day. Fences and posts in this study were of a similar height $(\sim 1.25 \mathrm{~m}$ tall) and likely used by the owls as perches to increase their field of vision (Andersson et al. 2009) and maximize detection of predators. Increased visual detection should shorten response time (Devereux et al. 2006) and therefore increase the probability of successfully reacting to a threat (Kenward 1978, Fitzgibbon 1990, Krause \& Godin 1996). If male owls were only concerned with detecting predator threats to themselves they would not need to remain near the nest burrow during the day. Owls presumably stay near the nest because they are not only avoiding predators, but also communicating threats to the young and female.

Paved, gravel, and some dirt roads in our study area are raised above the surrounding prairie, and most owls in our study had at least one road of this type near their nest. Owls may be attracted to roads with low traffic speeds because there is increased visibility when roads are used as perches, but these raised types of roads could also represent visual barriers. If owls choose to nest near roads that are visual barriers, they need a raised perch, such as a fence or the road surface itself, to see avian predators approaching from the direction of the road. This is doubly important not only because visibility is reduced when nesting near a road, but also because diurnal raptors follow roads while hunting (Meunier et al. 2000).

Owls were attracted to shorter perches, but may avoid taller perches. Though only available to a small portion of our sample of owls, perches $>2 \mathrm{~m}$ tall (power lines and tall shrubs) were not used by any individuals. Larger raptors such as hawks prefer taller perches (Bohall \& Collopy 1984, Berkelman et al. 2002, Leyhe \& Ritchison 2004) because of increased prey visibility (Andersson et al. 2009). Increased risk from other raptors is the most likely reason why burrowing owls do not use these taller perches.
Results from this study provide evidence that perches are valuable features for adult male burrowing owls while roosting during the day. Whether perches increase survival of eggs, nestlings, fledglings, or adults is not known, but owls likely consider the presence of vantage points when selecting nest sites. Thus, removal of perches around the nest may hinder their ability to be effectively vigilant and detect predators during the day. Though we found perches to be important to owls during the day, we are hesitant to recommend installation of additional perches near burrowing owl nests because this could also increase the presence of other avian predators (Kay et al. 1994) and potentially increase owl mortality. If perches are installed near active owl nests, we recommend they be added as part of a research program that would monitor owl response and nesting attempt success. Such an experiment could be used to identify the quantity and configuration of perches that result in the greatest benefit to the owls. Overall, further work is required to determine the net benefit of perches to burrowing owl demography. Burrows (both nest and secondary) are important for owls during the day, and we know owls choose nest burrows surrounded by more burrows (Poulin et al. 2005). The features that owls use and select (perches and burrows) within $250 \mathrm{~m}$ of the nest (average maximum distance travelled from the nest) should be left undisturbed to avoid potentially affecting nesting attempts.

Traffic and most other human disturbances will always be highest during the day, concurrent with the resting period for nocturnal birds. More effort needs to go into understanding the needs of these nocturnal species during the day to avoid disturbing them when they are vulnerable to predation and disturbance from humans.

Acknowledgements. Thank you very much to the following agencies who funded this research: Agriculture and AgriFood Canada; Alberta Sustainable Resource Development; Alberta Sport, Recreation, Parks and Wildlife Foundation; Canadian Association of Petroleum Producers; Canadian Land Reclamation Association; Canadian Natural Resources Ltd.; Cenovus Energy; ConocoPhillips Canada; Department of National Defence (Suffield); Environment Canada; Husky Energy; Nexen Inc.; Natural Sciences and Engineering Research Council of Canada; PennWest Energy; and Saskatchewan Fish and Wildlife Development Fund. We greatly appreciate the help of the many field technicians who helped collect data, and a special thanks to Alan Marsh for his invaluable assistance through-out the project. Also, we are very grateful to the landowners and land managers who allowed us access to their land and owls. Without their cooperation, this project would not have been possible. 


\section{LITERATURE CITED}

Aldridge CL, Boyce MS (2007) Linking occurrence and fitness to persistence: habitat-based approach for endangered greater sage-grouse. Ecol Appl 17:508-526

Andersson M, Wallander J, Isaksson D (2009) Predator perches: a visual search perspective. Funct Ecol 23: 373-379

> Bee MA, Swanson EM (2007) Auditory masking of anuran advertisement calls by road traffic noise. Anim Behav 74: 1765-1776

Belthoff JR, Ritchison G (1990) Roosting behavior of postfledging eastern screech-owls. Auk 107:567-579

Berkelman J, Fraser JD, Watson RT (2002) Nesting and perching habitat use of the Madagascar fish-eagle. J Raptor Res 36:287-293

Besnard F, Hamet JF, Lelong J, Le Duc E, Furst N, Doisy S, Dutilleux G (2009) Road noise prediction 1 - calculating sound emissions from road traffic. SETRA, Bagneux

Bivand R (2013) Spdep: spatial dependence: weighting schemes, statistics and models. R package v0.5-6.4

Bohall PG, Collopy MW (1984) Seasonal abundance, habitat use, and perch sites of 4 raptor species in north-central Florida. J Field Ornithol 55:181-189

Brittan-Powell EF, Lohr B, Hahn DC, Dooling RJ (2005) Auditory brainstem responses in the eastern screech owl: an estimate of auditory thresholds. J Acoust Soc Am 118: 314-321

Brumm H (2004) The impact of environmental noise on song amplitude in a territorial bird. J Anim Ecol 73: 434-440

Burnham KP, Anderson DR (2002) Model selection and multimodel inference: a practical information-theoretic approach. Springer-Verlag, New York, NY

Calenge C (2006) The package 'adehabitat' for the R software: a tool for the analysis of space and habitat use by animals. Ecol Model 197:516-519

Chipman ED, McIntyre NE, Strauss RE, Wallace MC, Ray JD, Boal CW (2008) Effects of human land use on western burrowing owl foraging and activity budgets. J Raptor Res 42:87-98

Churchill JB, Wood PB, Brinker DF (2000) Diurnal roost site characteristics of northern saw-whet owls wintering at Assateague Island, Maryland. Wilson Bull 112:332-336

> Devereux CL, Whittingham MJ, Fernandez-Juricic E, Vickery JA, Krebs JR (2006) Predator detection and avoidance by starlings under differing scenarios of predation risk. Behav Ecol 17:303-309

Federal Highway Administration (1999) Truck characteristics analysis. US Department of Transportation, Washington, DC

Fitzgibbon CD (1990) Why do hunting cheetahs prefer male gazelles? Anim Behav 40:837-845

Gitzen RA, Millspaugh JJ, Kernohan BJ (2006) Bandwidth selection for fixed-kernel analysis of animal utilization distributions. J Wildl Manag 70:1334-1344

Glenn EM, Hansen MC, Anthony RG (2004) Spotted owl home-range and habitat use in young forests of western Oregon. J Wildl Manag 68:33-50

Gotmark F, Blomqvist D, Johansson OC, Bergkvist J (1995) Nest site selection: a trade-off between concealment and view of the surroundings? J Avian Biol 26:305-312

Grzywaczewski G (2009) Home range size and habitat use of the little owl Athene noctua in East Poland. Ardea 97: 541-545
Hayward GD, Garton EO (1984) Roost habitat selection by three small forest owls. Wilson Bull 96:690-692

ISO (International Organization for Standardization) (2010) ISO 3746, acoustics - determination of sound power levels of noise sources using sound pressure - survey method using an enveloping measurement surface over a reflecting plane. International Organization for Standardization, Geneva

Kay BJ, Twigg LE, Korn TJ, Nicol HI (1994) The use of artificial perches to increase predation on house mice (Mus domesticus) by raptors. Wildl Res 21:95-106

- Kenward RE (1978) Hawks and doves - factors affecting success and selection in goshawk attacks on woodpigeons. J Anim Ecol 47:449-460

Kerth G, Weissmann K, Konig B (2001) Day roost selection in female Bechstein's bats (Myotis bechsteinii): a field experiment to determine the influence of roost temperature. Oecologia 126:1-9

> Krause J, Godin JGJ (1996) Influence of prey foraging posture on flight behavior and predation risk: predators take advantage of unwary prey. Behav Ecol 7:264-271

> Lampe U, Schmoll T, Franzke A, Reinhold K (2012) Staying tuned: grasshoppers from noisy roadside habitats produce courtship signals with elevated frequency components. Funct Ecol 26:1348-1354

Leyhe JE, Ritchison G (2004) Perch sites and hunting behavior of red-tailed hawks (Buteo jamaicensis). J Raptor Res 38:19-25

Magana M, Alonso JC, Martin CA, Bautista LM, Martin B (2010) Nest-site selection by great bustards Otis tarda suggests a trade-off between concealment and visibility. Ibis 152:77-89

Manly BFJ, McDonald LL, Thomas DL, McDonald TL, Erickson WP (2002) Resource selection by animals: statistical design and analysis for field studies. Kluwer Academic Publishers, Dordrecht

Martin DJ (1973a) Selected aspects of burrowing owl ecology and behavior. Condor 75:446-456

Martin DJ (1973b) A spectrographic analysis of burrowing owl vocalizations. Auk 90:564-578

Martin TE, Li P (1992) Life history traits of open- vs. cavitynesting birds. Ecology 73:579-592

> Meunier FD, Verheyden C, Jouventin P (2000) Use of roadsides by diurnal raptors in agricultural landscapes. Biol Conserv 92:291-298

Parris KM, Schneider A (2009) Impacts of traffic noise and traffic volume on birds of roadside habitats. Ecol Soc 14. www.ecologyandsociety.org/vol14/iss1/art29/

Pater LL, Grubb TG, Delaney DK (2009) Recommendations for improved assessment of noise impacts on wildlife. J Wildl Manag 73:788-795

Plumpton DL, Lutz RS (1993) Influence of vehicular traffic on time budgets of nesting burrowing owls. J Wildl Manag 57:612-616

Poulin RG, Todd LD (2006) Sex and nest stage differences in the circadian foraging behaviors of nesting burrowing owls. Condor 108:856-864

Poulin RG, Todd DL, Dohms KM, Brigham RM, Wellicome TI (2005) Factors associated with nest- and roost-burrow selection by burrowing owls (Athene cunicularia) on the Canadian prairies. Can J Zool 83:1373-1380

Quinn GP, Keough MJ (2002) Experimental design and data analysis for biologists. Cambridge University Press, Cambridge

R Development Core Team (2012) R: a language and envi- 
ronment for statistical computing. R Foundation for Statistical Computing, Vienna

Reijnen R, Foppen R, Terbraak C, Thissen J (1995) The effects of car traffic on breeding bird populations in woodland. 3. Reduction of density in relation to the proximity of main roads. J Appl Ecol 32:187-202

Reijnen R, Foppen R, Meeuwsen H (1996) The effects of traffic on the density of breeding birds in Dutch agricultural grasslands. Biol Conserv 75:255-260

Rheindt FE (2003) The impact of roads on birds: Does song frequency play a role in determining susceptibility to noise pollution? J Ornithol 144:295-306

Shyry DT (2005) Western burrowing owls (Athene cunicularia hypugaea) in southeast Alberta: juvenile survivorship from fledging to migration, effect of tags, and lateseason diets. MSc thesis, University of Alberta, Edmonton

Sissons RA (2003) Food and habitat selection of male burrowing owls (Athene cunicularia) on southern Alberta grasslands. MSc thesis, University of Alberta, Edmonton

Stephen S (2005) Road traffic noise. In: Fwa TF (ed) The handbook of highway engineering. CRC Press, Boca Raton, FL

Editorial responsibility: Al Glen,

Lincoln, New Zealand
Sunde P, Bolstad MS, Desfor KB (2003) Diurnal exposure as a risk sensitive behaviour in tawny owls Strix aluco? J Avian Biol 34:409-418

Wellicome TI (2000) Effects of food on reproduction in burrowing owls (Athene cunicularia) during three stages of the breeding season. PhD dissertation, University of Alberta, Edmonton

Wellicome TI, Haug EA (1995) Updated report on the status of the burrowing owl (Speotyto cunicularia) in Canada. Committee on the status of endangered wildlife in Canada, Ottawa

- Williams PJ, Gutierrez RJ, Whitmore SA (2011) Home range and habitat selection of spotted owls in the Central Sierra Nevada. J Wildl Manag 75:333-343

Winchell CS (1999) An efficient technique to capture complete broods of burrowing owls. Wildl Soc Bull 27: 193-196

Zuur AF, Ieno EN, Smith GM (2007) Analysing ecological data. Springer, Heidelberg

> Zuur AF, Ieno EN, Elphick CS (2010) A protocol for data exploration to avoid common statistical problems. Methods Ecol Evol 1:3-14

Submitted: May 29, 2013; Accepted: December 23, 2013 Proofs received from author(s): March 31, 2014 